\title{
Oil Exploitation and Agricultural Commodity Export in Nigeria: An Empirical Evaluation of the Extent and Impact of the Dutch Disease
}

\author{
Ogbonna, Innocent Chukwuka ${ }^{1}$, Uwajumogu, Nkechinyere R. (PhD) ${ }^{1}$ \\ Chijioke, Godwin ${ }^{2}$ Nwokoye, Ebele S. \\ ${ }^{I}$ Department of Economics, Renaissance University, Ugbawka, Enugu State, Nigeria \\ ${ }^{2}$ Department of Banking and Finance, Renaissance University, Ugbawka, Enugu State, Nigeria \\ ${ }^{3}$ Department of Economics, Nnamdi Azikiwe University, Awka, Anambra State
}

\begin{abstract}
The study examined the impact of crude oil discovery, exploitation and exportation on the agricultural commodity export (AGO) in Nigeria in the period 1970-2011. Specifically, the study sought to evaluate how the discovery and exportation of crude oil has impacted on the production and export of agricultural output. Annual time series data sourced mainly from the Central Bank of Nigeria (CBN) statistical bulletins for various years were analyzed using co-integration and vector error correction model in a bid to delineate the long run relationship between $(A G O)$ and oil export $(O X)$. Our results show that in the long run, Dutch disease (DD) is present in Nigeria. A $1 \%$ increase in OX will depress AGO by $16 \%$, that is, the more Nigeria produces and exports oil, the lower the output and less competitive the traditional tradable sector (AGO) becomes. The paper recommends that policy makers should make considerable investments in developing other economic sectors, re-channel the extra revenue from oil to accumulate income-producing foreign assets, and come up with a number of tax and import duty waivers, import substitution and diversification measures in order to boost productivity in the "lagging" traditional tradable sector and develop other agro-allied industries to improve the value chain.
\end{abstract}

Keywords: Agricultural Export, Booming Oil Sector, Dutch Disease, Lagging Tradable Sector, Nigerian Economy,

\section{Introduction}

Nigeria's external sector has remained the same since independence in 1960 - characterized by the dominance of a single export commodity. In the decades of 1960s and 1970s, the external sector was dominated by agricultural commodity export. It accounted for about $50 \%$ of the GDP, employed more than $75 \%$ of the labour force and produced over 70\% of total food consumption (Reynolds, 1966)[1]. Perhaps, more significant was the sector's foreign exchange earning capacity. In the 60s, Nigeria was the world's largest exporter of groundnut, the second largest exporter of cocoa and palm produce, and occupied a prominent position in rubber, cotton, and hides and skin export (WB 1975)[2]. In real terms, the country produced the following tones: $305,000,800,000$, and over 1,000,000 of cocoa, palm oil and kernel, and groundnut respectively (CBN, 2000)[3]. As percent share in total export, agricultural commodity export accounted for approximately $71 \%$ before the 70s (Iyoha, 2002)[4] and was the predominant earner of foreign exchange used to pay for imported manufactured goods. Thus, agricultural commodity export dominated the external sector accounting for about $77 \%$ of foreign exchange earnings in the first decade of independence.

The world-class performance of the primary agricultural commodity export could not be sustained as from the mid 70s. The discovery of oil in Nigeria by the Shell D'Arcy (now Shell BP) in 1956 and its first export of crude consignment in 1958 (WB 1975)[2] marked the beginning of oil exploitation in Nigeria. The production of crude oil which is of the light and sweet type and highly sought after in the international oil market, and the unrest in the Persian Gulf in 1973, which led to the four-fold increase in the per barrel price of crude marked the era of oil boom. From 1975 to 2011 crude oil export dominated the external sector accounting for between $92.7 \%$ and $98.7 \%$ of total export. As percent of federal government revenue, oil export dominated the external sector earnings accounting for 26.3 in 1970, 77.5 in 1975, 83.5 in 2000, 85.8 in 2005, and 73.9 in 2010 (TABLE 1.1). The foregoing suggests the unimpressive and "lagging" performance of the traditional agricultural exportable in the past three decades. According to Bitrus (2011)[5], agriculture was relegated to the background both as occupation and as a major foreign exchange earner. Most Nigerians hitherto employed in the sector, moved to the 'now booming' sector of the economy which was at that time providing over $90 \%$ of the nation's revenue. However, shortly after the collapse of agricultural sector and its domination by the 'newly' discovered oil, the situation changed. From 2.5 million barrels per day and 40 dollars price tag per barrel, oil 
production fell to less than 1 million barrels per day and less than 30 dollars per barrel in 1979 (FGN 1983[6] in Bitrus 2011)[5].

The policy concern over the years has therefore been to expand the non-oil export in a bid to diversify the country's export base. The diversification of the nation's economy is important for many reasons. Firstly, the sale of oil and its products and government revenue from these were not sustainable during the past decades due largely to the volatility in the international oil market. Secondly, crude oil is an exhaustible resource and therefore unreliable for sustainable development. Thirdly, to overcome the known and unimpressive feature of the Nigerian external sector - the dominance of a single export commodity since independence.

The wholesale adoption of the IMF induced Structural Adjustment Programme (SAP) in the second part of 1986 (Ogbonna, et al, 2012)[7], the foundation membership of World Trade Organisation (WTO) in 1995, and the adoption of the Export Processing Zone (EPZ) policy in 1999 ushered in diversification, deregulation and the restructuring of the productive base with positive bias for the production of agricultural exports. The foreign exchange reform that facilitated the cumulative depreciation of the effective exchange rate was expected to increase the domestic prices of agricultural exports and therefore boost domestic production.

However, despite these pro -diversification and -deregulation policies, the growth in the supply of primary agricultural products for export has remained sluggish relative to the oil export. Specifically, while the former as proportion of total export was $97.3 \%$ in 1960 , and $42.4 \%$ in 1970 , the latter was $2.7 \%$ and $57.6 \%$ respectively in the same periods. However, in 1989, agricultural exportable fell drastically to $5.1 \%$ and further to $2.3 \%$ in 2006 before rising marginally and insignificantly to $3.6 \%$ in 2010 . On its part, oil export, instead rose to $94.9 \%$ in 1989 , further to $97.7 \%$ in 2006 before falling marginally and insignificantly to $96.4 \%$ in 2010 (TABLE 1.1).

The rise in the exploitation and export of natural resource (oil) side by side with the decline in agricultural export symbolizes the Dutch Disease (DD). The DD called the resource curse or the "curse of oil" is an affliction that often affects relatively small resource-rich countries as a result of the exploitation and export of natural resources. The concept was coined from the experience of Netherlands in the 60s when, as a result of the exploitation and subsequent export of the newly discovered large deposits of natural gas in the North Sea, the manufacturing tradable sector became less competitive, declined and assumed "lagging" tradable sector with a ripple effect on the whole economy which also declined. The objective of this paper is therefore to determine the extent of DD in Nigeria and its impact on the economy taking the agricultural sector as the traditional declining tradable sector. The study is for the period 1970 to 2011.

The knowledge gap this work intends to fill is the empirical examination of the extent and impact of DD in Nigeria since the discovery of oil, hence addressing the countries specific dimension to oil exploitationDD debate. The study is different from previous studies as the agricultural sector is taken as the traditional tradable sector as against earlier studies that took the manufacturing sector as the declining tradable sector in the Least Developed Countries (LDCs) (see for example Kuralbayeva, et al, 2001[8]; Roemer, 1985)[9]. In this context, the study takes as a point of departure the empirical evaluation of the extent and impact of DD in a small open economy, Nigeria, using agricultural sector as the declining tradable sector. The rest of the work is structured as follows: section 2 examines the DD theory and literature. Section 3 presents the model and data sources; section 4 presents econometric methodology and discusses the results while section 5 concludes the work.

Table 1.1: Agricultural Commodity Export, Oil Export and Real Effective Exchange Rate (REER) in Nigeria: 1960-2011

\begin{tabular}{|c|ccc|ccc|c|}
\hline \multirow{2}{*}{ YEAR } & \multicolumn{2}{|c|}{ AGRICULTURAL PRODUCTION } & \multicolumn{3}{c|}{ OIL PRODUCTION } & \multicolumn{2}{c|}{ REAL EFFECTIVE } \\
& $\%$ & \% TOTAL & \% TOTAL & \% & \% TOTAL & \% TOTAL & EXCHANGE RATE \\
& GDP & EXPORT & REVENUE & GDP & EXPORT & REVENUE & (REER)* \\
1960 & 63.9 & 97.3 & 89.6 & 6.9 & 2.7 & - & NA \\
1970 & 41.3 & 33.1 & 73.7 & 11.5 & 58.2 & 26.3 & NA \\
1975 & - & 7.4 & 22.5 & 17.2 & 92.6 & 77.5 & NA \\
1980 & 20.6 & 2.1 & 35.8 & 21.4 & 96.1 & 64.2 & NA \\
1990 & 32.7 & 1.3 & 26.7 & 37.5 & 97.1 & 73.3 & NA \\
1995 & 31.6 & 1.2 & 29.4 & 39.6 & 97.6 & 70.6 & 18.01 \\
2000 & 33.8 & 1.3 & 16.5 & 47.7 & 98.7 & 83.5 & 58.25 \\
2005 & 32.8 & 1.7 & 14.2 & 38.9 & 98.3 & 85.8 & 143.78 \\
2010 & 35.2 & 3.6 & 26.1 & 33.4 & 96.4 & 73.9 & 92.38 \\
2011 & 30.9 & 3.9 & 24.9 & 35.9 & 96.1 & 75.1 & 89.91 \\
\hline
\end{tabular}

*Note: 1996-2007 base period is May 2003; 2008-2011 base period is November 2009 ; NA= Not Available.

Source: CBN Statistical Bulletin, various years

\section{Theory and Literature Related to Dutch Disease}

One of the well known economic models on DD is found in the seminal work of Corden and Neary (1982)[10]. Known as the 'Spending Effect' and 'Resource Movement Effect', this model is used to describe 
the mechanisms of the paradoxical deleterious consequence of natural resource exploitation on the countries where they occur. DD is an economic term and was first used in the magazine 'The Economist' in 1977 to describe the negative correlation between natural resource exploitation and economic growth if harmonious management and diversification strategy are not pursued after having acquired the windfall profit from increased price of natural resource. In their core model, Corden and Neary in explaining the spending and resource movement effects divided the open economy into three sectors - the booming export sector (B), which centres on natural resource discovery and the ensuing exploitation. The lagging export sector (L), which often is the traditional manufacturing activity (traditional agriculture in our case here), and the non-tradable sector $(\mathrm{N})$, which consists of goods and services produced only for domestic consumption. B and L produce tradable goods and face given world price. All outputs are produced specifically by the factors that belong to each sector and labour is domestically mobile between all sectors. They then showed that the lagging traditional tradable sector (L) is crowded out by the other two sectors $\mathrm{B}$ and $\mathrm{N}$ as a result of an appreciation of the real exchange (REER) of the domestic currency (guilder) following the large inflow of foreign currency, resulting from sharp surge in natural resource prices and resource movement away from $\mathrm{L}$ which makes the traditional lagging exports (L) less competitive and therefore less attractive to importers.

Corden (1984)[11] explains three reasons why the boom has occurred: The first is a once-for-all exogenous technical improvement in B, represented by a favourable shift in the production function, confined within the country concerned. Two, there has been a windfall discovery of the new resources which increased in supply of the specific factor, and, three, B produces only for export, with no sales at home and there has been an exogenous rise in the price of its product on the world market relative to the price of imports.

The spending effect occurs when some part of extra income made in B is spent either directly by the employer or indirectly by the government through extra tax revenue from B. This extra spending would produce an appreciation of the real exchange rate so that if the income elasticity of demand for $\mathrm{N}$ is positive, its price becomes higher and more profitable to produce compared to tradable. This increase in price of $\mathrm{N}$ caused by increase in the demand of $\mathrm{N}$ derived from the occurrence of the resource boom is spending effect. On the other hand, resource movement effect is the reaction derived from the boom in natural resource sectors that requires more labour into B. But because the domestic non-tradable goods sector also thrives, labour shift comes at the expense of the lagging export sector, which is already under performing due to the unfavourable real exchange rate appreciation. Thus, according to Corden and Neary (1982)[10], the movement of labour out of L into B lowers output in L, and they called it de-industrialization. This shift occurs with no effect on the real exchange rate and hence on $\mathrm{N}$ market. There is also a movement of labour out of $\mathrm{N}$ into $\mathrm{B}$ at a constant real exchange rate, but because the demand for $\mathrm{N}$ has risen due to increase in both output and revenue of $\mathrm{B}$, these jointly brings about labour shift from $\mathrm{L}$ into $\mathrm{N}$ dropping the demand and output of $\mathrm{L}$. As a result, the natural resource boom (direct de-industrialization) reduces both the demand and output of L but increases that of $\mathrm{N}$ (indirect de-industrialization). In other words spending effect tends to make output of $\mathrm{N}$ higher than initial situation and resource movement effect tends to leave it unaffected.

Ruehle and Kulkarni(2007)[12] further assert that the DD can also be explained by examining the effect of resource discovery, exploitation and subsequent rise in income in the domestic economy. An increase in the exports of B results to inflow of reserves and in the 'broadly defined' money supply (MS), such that:

$M S=M_{d}+R_{f}$

Where MS is broad money supply, $M_{d}$ is domestic money supply, and $R_{f}$ is foreign reserves. Any positive change in either the $\mathrm{M}_{\mathrm{d}}$ or $\mathrm{R}_{\mathrm{f}}$ result in increase in MS and hence inflation in the domestic economy. An increase in the export price of $B$ will increase the $\mathrm{R}_{\mathrm{f}}$, increase MS and hence inflation.

Ebrahim-Zadeh (2003)[13] notes that the weakening of the competitiveness of the lagging export sector is irrespective of the exchange rate regime the country operates - the REER appreciates whether fixed of floating. However, it should be noted that while in the developed countries (DCs), the industrial sector is the traditional tradable sector, in the Least Developed Countries (LDCs), the traditional tradable sector, which is crowded out with a resource boom is most often the agricultural sector. Corden and Neary (1982)[10], Stijns (2003)[14] call the case in DCs "de-industrialization" and Stijns (2003)[14] calls it "de-agriculturation" in the LDCs if the DD takes effect.

Henry (1991)[15] in Bitrus (2011)[5], indicated that in the middle of 1980, Nigeria was the only country out of six countries (Nigeria, Indonesia, Algeria, Iran, Venezuela, Trinidad and Tobago), where the quality of life of its citizens had fallen below the shock level. He thus summarized the performance of Nigerian economy into three main points as follows:

i) The specific uses to which petroleum revenue was put conditioned the structure of socio-political sharing. The social interest and class contrast were low because the state was under pressure to render services to the people which continued from military government to military government.

ii) There was no much pressure to use petroleum revenue to ameliorate the agricultural sector productivity. This is where Nigeria differs from Indonesia in the study. In Indonesia, petroleum revenue was used to ameliorate the 
agricultural sector. In Nigeria, that was not done. Thus, Indonesia progressed, while Nigeria declined economically.

iii) Macroeconomic adjustment of Nigeria led to declining national revenue, and this differs from other petroleum exporting countries. Indonesia adopted a rapid exchange rate between 1978 and 1980 in form of devaluation. Venezuela, Trinidad and Tobago experienced a large devaluation in 1981 without any hesitation on such adjustment.

By the forgoing analysis, Nigeria seems to be cited in some works as an example of a country with the characteristics of the DD in West Africa. This is as a result of a fall in the exportation of the non-oil sector, particularly agricultural products such as cocoa, groundnut, cotton, tin and columbite and palm oil. The resultant effect was that petrol became the only exporting sector. Coussy (1991)[16] has maintained that while Cameroon, on the other hand, seems to have escaped the DD, the potential difficulties involved in relying on primary exports have been on the export prices and revenue instability, declining terms of trade, and balance of payment crises resulting from the collapse of primary exports market prices.

Utomi (2003)[17] in Bitrus (2011)[5] has asserted that every oil windfall has created policy shocks that have increased uncertainty and resulted in retrenchment rather than real growth of the Nigerian economy. $\mathrm{He}$ further cited definite instances to corroborate his stance as follows:

The Yom Kippur War windfall of 1973 facilitated the Udoji awards and the damage to the consumption ethic of Nigerians, which hunts us today. The Iranian revolution windfall of 1979/80 sets us up for DD after DD as expanding budget begot the open general license for imports that led us down the path of debt crisis. The ultimate was 1991 windfall following the Gulf War which increased our recklessness so much that in the year of that windfall we ended up with perhaps the worst deficit we had up to that point, creating the inflationary pressures that did havoc to real incomes".

Olusi and Olanguju (2005)[18] noted that while labour migrate from the traditional tradable sector to the booming tradable sector leading to a decline in the former in DCs, migration of labour in the LDCs is rather from the traditional tradable to the non-tradable small manufacturing sector also leading to a decline in the former. Except for the retail outlets in the booming tradable sector, the high skill required in the capitalintensive segments of the oil sector is in short supply in the LDCs. FOS (1996)[19] report that the proportion of the labour force engaged in agricultural sector increased from 56.6\% to $60.4 \%$ from 1984-1994 is in tandem with this proposition. In support of the proposition that the high skill required in the capital-intensive segments of the oil sector is in short supply in the LDCs, Ajakaiye (2001)[20] submits that the oil sector is mainly extractive with little linkage to the domestic economy. The booming oil sector thus remains largely an enclave industry that it had been since its discovery, hence, in Nigeria, as in many other LDCs, labour instead, migrates to the non-tradable sector of building and construction, services and the relatively small modern import substituting manufacturing sector.

\section{II.1 Empirical Literature}

The empirical literature on DD may be grouped into two: those studies relating to DCs and those relating to LDCs. On DCs, Jimenez-Rodriguez and Sanchez (2003)[21] results of their investigation on whether oil exploitation and exportation benefited Norway and United Kingdom (UK) are mixed. While their results showed that Norway benefited significantly from oil price increases, such increase in the price of oil showed a significant negative impact on the UK GDP growth. Similarly, Ross (1986)[22] also investigated the case of DD in the UK and found that after discovery and exploitation of crude oil in the country from 1975, REER appreciated by between $51 \%$ to $55 \%$ in the period 1977 to 1980 leading to the decline in the manufacturing output from 4\% in the period 1973 and 1979 to $14 \%$ between 1979 and 1982 .

Ellman (1981)[23] reports that as a result of the exploitation and export of large deposits of natural gas in the North Sea in Holland, the textile and clothing industries nearly varnished, while others - metal manufacturing, vehicles, ships, mechanical engineering and construction industries decline. The report showed that only services (non-tradable) sector expanded. Stijns (2003)[14] in a comprehensive study using World Trade Data, found that energy-price led booms have systematically tended to hurt energy exporters' manufacturing exports.

As for LDCs, Warr (1985)[24] asserts that the Indonesian economy, though witnessed energy boom which had distinctive effects on domestic prices, it is not clear that the structure of her economy was affected by the DD due largely to prudent management of her exchange rate. Other studies, Kuralbayeva, et al (2001)[8], Roemer (1985)[9], Jazeyeri (1986)[25] reject the presence of DD function on LDCs investigated. Olusi and Olagunju (2005)[13] examined the existence of DD in Nigeria using quarterly data of variables of interest and adopting VAR model consisting of impulse response functions and variance decomposition analyses found evidence of DD in Nigerian economy, albeit, as a delayed occurrence. The duo recommends that Nigerian government should lay more emphasis on the agricultural sector hitherto not given deserved attention. Other studies for Nigeria (Abdullahi, 1981[26], Chukwuemeka and Nzewi, 2011[27], Sekumade, 2009)[28] all found 
evidence of DD and affirmed that agricultural sector was neglected during the oil boom era.

Aliyu (2011)[29] in his empirical work using graphic descriptive statistics and the one-way analysis of variance technique, sought to know whether the neglect of agricultural sector was as a result of the discovery and exploitation of oil in Nigeria during the oil boom period of 1973-1983. The study found a significant increase in the quantity of capital expenditure allocated to agricultural sector during the oil boom period and that more capital expenditure was allocated to agricultural sector than was allocated to either of health, education or defence sector in Nigeria during the period. He concludes by rejecting the hypothesis that the neglect of agricultural sector was as a result of oil boom.

\section{III.1 Model}

\section{Model, Data Sources, Measurement and Justification}

Having examined theoretically the DD situation in Nigeria, we turn to empirical examination of its extent, impact and attendant consequences on the agricultural output in Nigerian economy. We regress agricultural output proxied by non-oil export against oil export and other control variables. The intention is to determine the impact of oil exploitation and exportation on the agricultural production and exportation in Nigeria. In doing so, we are able to determine the extent and impact of DD in agricultural commodity export in Nigerian economy. Hence, following the works of Olusi and Olagunju (2005)[18], Bitrus (2011)[5], JimenezRodriguez and Sanchez (2003)[21], we represent the reduced form of a standard open economy macroeconomic model as a multivariate dynamic system and thus specify with some modifications, and proceed to test the long run relationship among the variables in the model:
$\mathrm{AGO}=\beta_{\mathrm{o}}+\beta_{1} \mathrm{OX}+\beta_{2} \mathrm{RGDP}+\beta_{3} \mathrm{REER}+\beta_{4} \mathrm{INF}+\beta_{5} \mathrm{OPN}+\mu$
a-priori $=(-) \quad(+) \quad(-) \quad(-) \quad(+)$

where: $\mathrm{AGO}=$ Agricultural commodity output (proxied by non-oil export revenue); RGDP $=$ Real Gross Domestic Product; OX = Crude Oil Export; REER = Real Effective Exchange Rate; INF = Inflation Rate; OPN $=$ Openness, and $\mu$ is the error term.

\section{III.2 Data Sources}

The macro data such as AGO, RGDP, OX, REER, INF and OPN for the estimation of the equation are sourced from CBN statistical bulletin various years and covered the period 1970-2011.

\section{III.3 Measurement and Justification of Variables}

The main activities in the Nigerian economy include agriculture, oil production and manufacturing. These three sectors constitute the major contributors to the country's export receipts. Exports of agricultural and manufacturing outputs together constitute non oil export (NOX) receipts. All efforts to expand the manufacturing sector of the economy and improve its contribution to export receipts since independence remained a far cry. Hence, for Nigeria, NOX consists traditionally of agricultural products both processed and unprocessed (Ogbonna, et al 2013)[30]. AGO will be proxied by NOX receipts.

Nigeria is a major producer of oil in the world. She is the $6^{\text {th }}$ producer member of Organization of Oil Exporting Countries (OPEC), the $11^{\text {th }}$ world producer, and the $5^{\text {th }}$ biggest supplier of crude oil to the United States (Bitrus, 2011)[5]. On yearly average, the sector contributes more than $95 \%$ of country's total export since 1980 (Ogbonna, et al 2013)[30]. The capacity of the sector to negatively influence substantially the nation's "lagging" sector and expose it to DD phenomenon is not in doubt. The variable is therefore expected to relate negatively with the AGO given the DD postulation.

Economic growth is measured by the rate of change of real GDP (RGDP). The expansion of an economy will increase its capacity to produce for export via imported technology (Okoh, 2004)[31]. Hence, RGDP is included in the model as determinant of AGO and is expected to relate positively with it.

Real Effective Exchange Rate (REER) is included to show the effect of an appreciation of real exchange rate which results from the high demand of domestic currency derived from the resource boom. An appreciation of exchange rate will depress the lagging traditional tradable goods sector, and hence impact negatively on the AGO.

Macroeconomic stability is an important factor for the attainment of higher economic growth through increased agricultural production. An improved macro-economy would lead to more incentives for firms and investors to invest and grow the agricultural output. A measure of macroeconomic stability employed is the inflation, mainly because of its importance in previous studies (Olusi and Olagunju (2005)[18], Bitrus (2011)[5].

With a low inflation there is likelihood for more investors showing interest in domestic production for export. This is because a rise in domestic prices relative to foreign prices will make domestic goods more expensive so that relatively domestic firms (residents) import more an export less. Inflation is expected to relate negatively with the dependent variable.

An open economy permits trade in the tradable goods/services sector. The degree of openness is 
measured as a ratio of total trade to GDP (Ogbonna, et al 2013)[30]. According to Olaniyi (2005)[32], the trade openness implemented in the post 1986 structural adjustment period contributed to Nigeria's export performance. Thus, it is expected that openness relates positively with the AGO in Nigeria.

\section{IV.1 Econometric Methodology}

In order to check the time series properties of the variables used in the model, we apply the unit root tests. We utilize the Augmented Dickey-Fuller (ADF) and Philips Perron (PP) unit root tests to investigate the order of integration of the variables in the model. Equation 2 which include a constant and trend term is used:

$$
\Delta \mathrm{Y}_{\mathrm{t}}=\beta_{1}+\beta_{2}+\mathrm{sY}_{\mathrm{t}-1}+\mathrm{SY}_{\mathrm{t}-1}+\sum_{t-1}^{m} \delta Y t-1+\varepsilon t
$$

where $\Delta=$ difference operator, $\mathrm{Y}_{\mathrm{t}}=$ each of the series, $\mathrm{Y}_{\mathrm{t}-1}=$ the lag of each series and $\varepsilon t$ is pure white noise satisfying all the classical assumptions. Equation 2 permits the test to determine if the variable $Y_{t}$ is a stationary series. The null hypothesis in the ADF/PP tests is that $Y_{t}$ is non-stationary, that is, has a unit root $\left(\mathrm{H}_{0}: \beta=0\right)$ and is rejected if $\beta$ is significantly negative $\left(\mathrm{H}_{\mathrm{a}}: \beta<0\right)$. If the calculated ADF/PP statistic is higher than McKinnon's critical values, then the null hypothesis $\left(\mathrm{H}_{\mathrm{o}}\right)$ is rejected and the series is stationary or integrated of order zero $\mathrm{I}(0)$. Alternatively, non-rejection of the $\mathrm{H}_{\mathrm{o}}$ implies non-stationarity leading to the conduct of the test on the difference of the series until stationarity is achieved and the $\mathrm{H}_{\mathrm{o}}$ is rejected.

Phillips and Perron (1988)[33] use a nonparametric method to correct for the serial correlation of the disturbances. The test is based on the estimate of the long run variance of residuals. There modification of the Dickey and Fuller $\Gamma$ test is called $Z(\Gamma)$ test. The critical values for $\Gamma \Gamma$ and $Z(\Gamma \Gamma)$ are the same if the residuals are generated by an independent and identical process. Although the Phillips and Perron (PP) tests and the Dickey and Fuller tests provide identical results, the power of the ADF tests is more than the PP tests in the presence of negative moving average components (Adeniyi 2010)[34].

\section{IV.2 Results}

Table 4.1: ADF and PP Unit Root Test Results

\begin{tabular}{|c|c|c|c|c|c|c|c|c|c|}
\hline \multirow{2}{*}{$\begin{array}{c}\text { Varia } \\
\text { bles }\end{array}$} & \multicolumn{2}{|c|}{ Level I(0) } & \multicolumn{2}{|c|}{$1^{\text {st }}$ Difference I(I) } & \multirow{2}{*}{$\begin{array}{c}\text { Variab } \\
\text { les }\end{array}$} & \multicolumn{2}{|c|}{ Level I(0) } & \multicolumn{2}{|c|}{$1^{\text {st }}$ Difference I(I) } \\
\hline & ADF & PP & ADF & PP & & ADF & PP & ADF & PP \\
\hline AGO & - & - & $-5.440 *$ & $-5.440 *$ & REER & - & - & $-6.170 *$ & $-6.170^{*}$ \\
\hline $\mathrm{OX}$ & - & - & $-7.700^{*}$ & $-7.700 *$ & INF & $-3.241 * * *$ & $-3.241 * * *$ & - & - \\
\hline RGDP & - & - & $-4.673^{*}$ & $-4.673 *$ & OPN & $-3.945^{* *}$ & $-3.945 * *$ & - & - \\
\hline ECM & $-4.648 *$ & $-4.648 *$ & - & - & OPN & $-3.945 * *$ & $-3.945 * *$ & - & - \\
\hline
\end{tabular}

(2) *,** and *** indicate statistical significance at the $1 \%, 5 \%$ and $10 \%$ level respectively

(3) McKinnon (1973)[35] critical values are: $-4.242(1 \%),-3.536(5 \%)$ and $-3.204(10 \%)$.

The results presented in TABLE 4.1 indicate that only INF and OPN are stationary at levels while AGO, OX, RGDP, and REER are non-stationary at levels. However, they became stationary after first difference, which implies they are I(I) series. Given the unit root properties of the series, we proceeded to test for actual numbers of co-integration equations that exist among the variables, that is, whether a long run cointegrating relationship exist among the variables in (1). Co-integration tests are undertaken based on the Johansen and Juselius (1990)[36] maximum likelihood framework. The purpose is to see whether there exists a long run equilibrium relationship among the variables. The results of the tests are presented in TABLE 4.2.

Starting with the null hypothesis $\left(\mathrm{H}_{\mathrm{o}}\right)$ that there are no co-integrating vectors $(\mathrm{r}=0)$ in the model, the results show that there exist at least one co-integrating (long run) relation in the model since both the trace $(\lambda-$ trace) and maximum Eigen $\left(\lambda\right.$ - max) statistics reject the $H_{0}$ of $r \leq 0$ against the alternate of $r \geq 1$ at the $5 \%$ level of significance. This is indicative of at least one co-integrating vector (three for trace statistic and one for maximum eigenvalue statistic) in the model which moves the relationship towards long run equilibrium. That there are three co-integrating vectors for trace statistic and one for maximum eigenvalue statistic suggest a conflict, but this is recognized in the literature and the argument is that since the trace statistic takes into account all of the smallest eigenvalues, it possess more power than the maximum eigenvalue statistic. Johansen and Juselius (1990)[36] recommend the use of the trace statistic when there is a conflict between the two statistics (TABLE 4.2). Thus, OX, RGDP, REER, INF and OPN co-integrate with agricultural commodity export (AGO), thereby confirming the presence of a fundamental long run relationship among the variables.

Given the stationary behavior of the agricultural commodity export (AGO) and its co-integration with oil export (OX) and other control variables, the most natural approach is an error correction model with OX as the long run anchor term. The significance of ECM in the model is to indicate how disequilibrium in AGO can be adjusted in the short run. Thus, we determine how AGO reacts in the long run to changes in OX in Nigeria. Following dynamic version of error correction model (ECM) is specified with some variables in their logarithmic form: 
Where: $\beta_{6}$ is the speed of adjustment of Nigeria's agricultural export sector to changes in oil export; Ln stands for natural log; ECM is the value of the residuals in (1); $\Delta, \beta_{0-5}$, OX, RGDP, REER, INF, OPN, and $\mu$ are as earlier defined.

Table 4.2: Results from Johansen Co-integration Rank Test (Trace) and (Maximum Eigen-value)

\begin{tabular}{|c|c|c|c|c|c|}
\hline $\begin{array}{c}\text { Null } \\
\text { Hypothesis }\end{array}$ & Trace Statistic & $\begin{array}{c}\text { Critical Value at 5 } \\
\text { per cent }\end{array}$ & Null Hypothesis & $\begin{array}{c}\text { Maximum-Eigen } \\
\text { Statistic }\end{array}$ & $\begin{array}{c}\text { Critical value at 5 } \\
\text { percent }\end{array}$ \\
\hline $\mathrm{r}=0^{*}$ & 189.1873 & 94.15 & $\mathrm{r}=0 *$ & 123.4878 & $94.15^{*}$ \\
\hline $\mathrm{r}=\leq 1^{*}$ & 95.2141 & 68.52 & $\mathrm{r}=\leq 1$ & 59.32279 & 68.52 \\
\hline $\mathrm{r}=\leq 2^{*}$ & 48.7798 & 47.21 & $\mathrm{r}=\leq 2$ & 47.21 & 54.46 \\
\hline $\mathrm{r}=\leq 3$ & 16.8648 & 29.68 & $\mathrm{r}=\leq 3$ & 29.68 & 35.65 \\
\hline $\mathrm{r}=\leq 4$ & 6.3894 & 15.41 & $\mathrm{r}=\leq 4$ & 15.41 & 20.04 \\
\hline $\mathrm{r}=\leq 5$ & 0.1011 & 3.76 & $\mathrm{r}=\leq 5$ & 3.76 & 6.65 \\
\hline
\end{tabular}

Note: $r$ represents number of co-integrating vectors. Trace test and Max. eigenvalue tests indicate 3 and 1 co- integrating equations respectively at the $5 \%$ level. * Denotes rejection of the null hypothesis at the $5 \%$ level.

From the estimates of (3) as presented in TABLE 4.3, the coefficient of ECM is -0.58 , which is a reasonably good adjustment process. The speed of adjustment which is significant at $5 \%$ is indicative that about $58 \%$ of the disequilibrium in the previous year's shock adjusts back to the long run equilibrium in the current year. Patterson (2000)[37] in Ogbonna, et al (2013)[30] asserts that the negative sign of the ECM coefficient is indicative that an increase is required through the independent variables.

Table 4.3: Error Correction Model (Results of (3))

\begin{tabular}{|cccccccc|}
\hline $\begin{array}{c}\text { Dependent } \\
\text { Variable }\end{array}$ & Constant & $\Delta$ OX & $\Delta$ RGDP & $\Delta$ REER & $\Delta$ INF & $\Delta$ OPN & ECM \\
$\Delta$ AGO & .0103606 & -0.15592 & $-8.03 \mathrm{e}-08$ & -0.001109 & -0.002079 & 0.050526 & -0.575532 \\
$\mathrm{P}>|\mathrm{z}|$ & 0.956 & 0.477 & 0.393 & 0.844 & 0.722 & 0.944 & 0.029 \\
Std. Err. & .1864557 & 0.21911 & $9.39 \mathrm{e}-08$ & .0056401 & .0058459 & .7183749 & .3384331 \\
\hline
\end{tabular}

Source: Authors' computation using Stata 11

\section{IV.3 Discussion}

The long run analysis reveals the existence of Dutch disease in Nigeria. With the negative coefficient of -0.15592 for oil export $(\mathrm{OX})$, it implies that a percent increase in OX will depress agricultural commodity export (AGO) by about 16\%, an indication that the discovery, exploitation and exportation of oil in Nigeria since the 70s has contributed in making the 'once upon a time' AGO less competitive, decline, and assume the "lagging" tradable sector. As a result, the expected contribution of AGO in growing the Nigerian economy is not being realized as attention shifts away into oil exploitation and exportation. The $\mathrm{P}>|\mathrm{t}|$ of 0.477 , however, is indicative of an insignificant impact. The finding is consistent with some studies for Nigeria (Olusi and Olagunju, 2005[18]; Bitrus, 2011)[5], but inconsistent with the findings of Aliyu (2011)[29], Roemer (1985)[9] and Jazayeri (1986)[25]. Aliyu study was on Nigeria; Roemer study was on Nigeria, Mexico and Venezuela; while Jazayeri studied Iran and Nigeria. Except for Aliyu, others however, assumed oil and manufacturing as the tradable sectors instead of agriculture and crude oil. In most developing economies, agriculture is the traditional export sector, while crude oil sector is relatively newly discovered.

Equivalently, with the negative coefficients of $-8.03 \mathrm{e}-08$ for RGDP, -0.0011 for REER and -0.0021 for INF, the implications are that increases in these variables depress AGO. Specifically, it implies that a percent change in RGDP will depress AGO by $803 \%$, an indication that the spending of extra revenue from oil hurt AGO as such are channeled towards the production and consumption of domestic goods and services. For REER it means that when it goes up (depreciates), AGO will grow but because of extra spending on non-tradable domestic goods and services, caused by extra revenue from oil, derived from resource (oil) boom (spending effect), the REER of the domestic currency (the naira) appreciates making the traditional agricultural export less competitive, less attractive to importers, lower farmers' income earnings, decline in output production and a reduction in export trade. On its part, the negative coefficient of inflation depicts its depressing effect on AGO. This is expected since the increase in the price of $\mathrm{OX}$ as a result of the boom leads to positive change in foreign reserves, increase in money supply (MS), rise in inflation and a depressing effect on AGO. However, the $\mathrm{P}>|\mathrm{t}|$ value for each of these variables is greater than 0.05 indicating an insignificant statistical relationship between the variables and AGO. OPN coefficient is 0.051 , implying that higher degree of openness will improve agricultural commodity export.

To redress this known feature of Nigeria since independence in 1960 - the dominance of a single export commodity - there is a need to diversify the economy away from oil based to other sectors such as agriculture, 
science and technology, manufacturing among others; and this will prevent Dutch disease by preserving these sectors from being crowded out by the oil sector. Policy makers should thus make considerable investments in developing other economic sectors as well as come up with a number of tax and import duty waivers and import substitution measures in order to boost productivity in these sectors, develop other agro-allied industries and hence improve the value chain. The central bank of Nigeria (CBN), Bank of Industry (BoI) and other specialized banks should collaborate in the area of providing intervention funds for the sectors at softer terms than obtainable in the open market. Finally, policy makers should re-channel the extra revenue from oil away from the production and consumption of domestic goods and accumulate instead income-producing foreign assets and thus reduce REER appreciation, improve AGO competitiveness and attraction to importers, increase farmers' export earnings, increase output production and hence increase export trade

\section{Conclusion}

The study empirically examined the presence of Dutch disease in Nigeria since the discovery, exploitation and exportation of oil. Cointegration technique and Vector Error Correction Model (VECM) were used to examine the long run and short run relationships respectively. The results show that agricultural commodity production for export (AGO) is influenced negatively by the discovery and exportation of oil in Nigeria. A $1 \%$ increase in oil export revenue and real GDP will depress agricultural commodity export proceeds by $16 \%$ and $803 \%$ respectively. Equally, a $1 \%$ appreciation of real effective exchange rate (REER) will impact negatively on traditional export proceeds by $001 \%$. The negative coefficient featured by oil export as a function of traditional agricultural exportable symbolizes the existence of DD or resource curse in Nigeria. From the results obtained, the main drivers of the lagging traditional export sector are oil export revenue and real GDP. It is evident from the study that extra revenue from oil has been hurting the AGO because the purpose and manner of usage always favour goods and services produced only for domestic consumption. It is imperative that the management and disbursement of the extra revenue from oil should be to accumulate income-producing foreign assets channeled towards diversification of the economy and improved methods of agricultural production for export so as to improve the supply of foreign exchange from other sectors, avoid further damage to agricultural commodity export, and hence, improve Nigerian economy.

Our study has demonstrated that contrary to some earlier findings (Aliyu (2011)[29], Roemer (1985)[9], Jazayeri (1986))[25], and consistent with some recent findings (Olusi and Olagunju, 2005[18]; Bitrus, 2011)[5], resource curse is present in Nigeria, but in the long run. Earlier works on Nigeria had used manufacturing export as the traditional declining tradable sector but this study instead used agricultural tradable sector as the sector crowded out (de-agriculturation) by the resource boom - the oil export. The existence of DD in Nigeria confirms the existing neglect on agricultural commodity production and export since the discovery of oil early 70 s.

\section{References}

[1] Reynolds, L. C. (1966). Peasant Agriculture and Economic Growth in Nigeria. The Economic Growth Center, Yale: Yale University

[2] World Bank (WB) (1975) Nigeria: Options for Long-term Development. Baltimore and London: The Johns Hopkins University Press

[3] Central Bank of Nigeria (CBN) (2000) The Changing Structure of the Nigerian Economy and Implications for Development, Lagos: Research Department (August) Iyoha, M.A. (2002) Explaining African Growth Performance: The Case of Nigeria. Revised Interim Report on Nigerian Case Study prepared for the African Economic Research Consortium Research Project titled:'Explaining African Economic Growth Performance" May 1-95

[5] Bitrus, N. B. (2011) An Evaluation of the Impact of the Dutch Disease on the Nigerian Economy (1970-2006) A Ph.D Thesis submitted to the School of Post-graduate Studies, University of Jos, in fulfillment of the requirements for the award of the degree of Doctor of Philosophy in Economics, (October)

[6] F. G. N. (1983). Oil Glut-Effects on the Nigerian Economy, what you should know. Published by Federal Department of Information, public Enlightenment Division, Lagos.

[7] Ogbonna, I.C, N.R. Uwajumogu, E. Nwokoye and G. Nzeribe (2012) Foreign Direct Investment and Economic Growth in Nigeria: An Empirical Investigation International Journal of Economics and Sustainable Development, Vol. 3 No. 13, November, pp.34-40

[8] Kuralbayeva, K., A. Kutan and M. Wyzan (2001) Is Kazakhstan Vulnerable to the Dutch Disease? Zentrumfur Europaische Integrations forschung Working Paper B.29, pp. 1-36

[9] Roemer, M. (1985) Dutch Disease in Developing Countries: Swallowing Bitter Medicine. In The Primary Sector in Economic Development: Proceedings of the Seventh Arne Ryde Symposium, (August)

[10] Corden, W. and J.P. Neary (1982) Booming Sector and De-industrialisation in a Small Open Economy. The Economic Journal, Vol. 92, No. 368 (December), pp. 825-848

[11] Corden, W. M. (1984). Booming sector and Dutch Disease Economics: Survey and Consolation. Oxford Econ.. Papers 36, 3:pp.359380

[12] Ruehle, A.A and K.G. Kulkarni (2007) in www.flang.keio.ac.jp/webfile/awc/awc2007/ug2 ym.pdf. 0 Size: 252 KB

[13] Ebrahim-Zadeh, C. (2003) Dutch Disease: To Much Wealth Managed Unwisely. Finance and Development Vol. 40, No. 1 pp.1-4 in Olusi, J.O. and M.A. Olagunju (2005) The Primary Sectors of the Economy and the Dutch Disease in Nigeria. The Pakistan Development Review 44:2, pp. 159-175

[14] Stijns, J. (2003) An Empirical test of the Dutch Disease Hypothesis using Gravity Model. Paper presented at the Congress of EEA, Stockholm, (August)

[15] Henry, (1991). Nigeria: From Windfall Gains to Welfare Looses? Sustaining Development in Mineral Economies. The resources curse thesis 
[16] Coussy, J. (1991). formes spécifiques du Dutch Disease en Afrique de l“Ouest : le cas du Nigeria et du Cameroon”.Revue Tiers Monde, No 125, Janvier/Mars.

[17] Utomi, P. (2003). Managing the Curse of Oil. «http://www.nigeriavillagesquarel.com/Articles/utomil.html»

[18] Olusi, J. O. and , M. A.Olagunju (2005). The Primary Sectors of the Economy and the Dutch Disease in Nigeria. The Pakistan Development Review 44 2: 159-175

[19] Federal Office of Statistics (FOS) (1996) Socio-Economic Profile of Nigeria. Lagos.

[20] Ajakaiye, O. (2001) Economic Development in Nigeria. Issues and Experience, in Proceedings of the First CBN Annual Monetary Police Conference titled, Growing the Nigerian Economy (November) pp 12-36

[21] Jimenez-Rodriguez, R. and M. Sanchez (2003) Oil Price Shocks and Real GDP Growth: Empirical Evidence for Some OECD Countries (Mimeographed)

[22] Ross, A. (1986) The United Kingdom's Experience with North Sea Oil and Gas. IDS Bulletin (October), pp. 14-21

[23] Ellman, M. (1981) Natural Gas, Restructuring and Reindustrialisation: The Ddutch Experience of Industrial policy. In T. Barker and V. Brailovsky (eds.) Oil or Industry. London: Academic Press.

[24] Warr, P. (1985) Indonesia's Other Dutch Disease. In P. Neary and S.V. Winbergen (eds.) Natural Resources and the Macroeconomy. Oxford: Basil Blackwell Ltd.

[25] Jazayeri, A. (1986) Prices and Output in Two Oil-based Economies: The Dutch Disease in Iran and Nigeria. IDS Bulletin (October), pp. 14-21

[26] Abdullahi, A. (1981). The Problems and Prospects of the Green Revolution for Agricultural and Rural Development of Nigeria: Technical and Environmental Perspectives. In Abalu, G.O.I., Abdullahi, Y. and Imam. A. M. (Eds). The Green Revolution in Nigeria? Proceedings of a National Seminar organised by the Department of Agricultural Economics and Rural Sociology, Ahmadu Bello University and held in Zaria, Nigeria from September 21st - 24th . pp 1-11

[27] Chukwuemeka, E. and Nzewi, H. N. (2011). An empirical study of World Bank agricultural development programme in Nigeria. American Journal of Social and Management Sciences 2(1): 176-187

[28] Sekumade, A. B. (2009).The effects of petroleum dependency on agricultural trade in Nigeria: An error correlation model-ing (ECM) approach. Scientific Research and Essay 4 (11) : 1385-1391

[29] Aliyu, A.A. (2011) Nigeria's Oilboom Period (1973-1983): Was Agriculture Real Neglected? International Journal of Statistics and Applications 1(1) 6-9

[30 Ogbonna,I.C., N.R. Uwajumogu, C. Godwin and S.V. Agu (2013) Economic Globalization: Its Impact on the Growth of Non-oil Supply in Nigeria International Journal of Economics and Sustainable Development, Vol. 4 No 7, May, pp. 66-74

[31] Okoh, R.N (2004) Globalization and Growth of Nigerian Non-oil Exports. A Paper Presented at the Centre for the Study of African Economies, African Conference, 2004, on Growth, Poverty Reduction and Human Development in Africa $21^{\text {st }}-22^{\text {nd }}$ March, 2004, Oxford, UK.

[32] Olaniyi, O. (2005) Nigeria's Trade Policy from 1960-2004: A Critical Review. Paper presented at the Workshop on Capacity Building on International Trade. National Assembly in Collaboration with Friedrich Ebert Stiftung (Nigeria), Jos. Pp. 25-27

[33] Phillips, P.C.B. and P. Perron (1988) Testing for a Unit Root in Time-Series Regression. Biometrika Vol. 75, pp. 335-346

[34] Adeniyi, O.A. (2010) Stock Market Development Indicators and Economic Growth in Nigeria (1990-2009): Empirical Investigations. CBN Economic and Financial Review, Vol. 48, No. 1 March, pp.33-70

[35] McKinnon, R.I. (1973) Money and Capital in Economic Development. Washington, D.C.: The Brookings Institute

[36] Johansen, S and K. Juselius (1990) Maximum Likelihood Estimation and Inference on Cointegration with Applications to the Demand for Money, Oxford Bulletin of Economics and Statistics, 52(2) 169-210

[37] Patterson, K. (2000): An Introduction to Applied Econometrics, A Time Series Approach. Palgrave Publishers in Ogbonna,I.C., N.R. Uwajumogu, C. Godwin and S.V. Agu (2013) Economic Globalization: Its Impact on the Growth of Non-oil Supply in Nigeria International Journal of Economics and Sustainable Development, Vol. 4 No 7, May, pp. 66-74 